\title{
CHEMICAL COMPOSITION AND ANTIOXIDANT ACTIVITY OF
}

\section{Pelargonium graveolens OIL}

\author{
S. H. Obeid \\ Researcher \\ B. M. Jaber \\ Assistant Prof.
}

Department of Biology ,Collage of Science for Women ,University of Baghdad, Iraq. sabahussein2015@yahoo.com

\section{ABSTRACT}

A comparison was conducted between volatile oil of the plant parts leaves and stems of Pelargonium graveolens as antioxidant by using the compound DPPH as a free radical. This study aimed at isolation and diagnosis the active compounds of the volatile oil .The volatile oil was extracted by using the water distillation Clevenger. Volatile oils were detected by using the liquid gas chromatography. The results showed that $100 \mathrm{~g}$ of leaves and steams produced a volatile oil estimated by $5 \%$ and $2.3 \%$ respectively. The study has shown that volatile oil of leaves contains 12compounds and the highest was Terpineol reaching $31.52 \%$, Camphor 7.06 $\%$ and Cis-alpha-Bisabolene $\mathbf{4 . 3 8 \%}$. The study showed that volatile oil in steams contains 10 compounds and Linalool represented the highest $(3.00 \%)$, followed by Camphor (2.76 \%), then (E) -B-Farnesene $(2.31 \%)$. The results also showed high volatile oil antioxidant activity in both leaves and steams at the concentration $125 \mu \mathrm{g} \mathrm{ml}^{-1}$ reached $100 \%$ compared with Ascorbic Acid when studying the effect of their oxidative effect on the free radical DPPH, the results also indicate significant differences between the volatile oil concentrations in both leaves and steams.

Keywords: Geranium, volatile oil, Ascorbic acid

$$
\text { قبا حبي التركيب الكيميائي والفاعلية المضادة للأكسدة لزيت نبات العطرة }
$$

sabahussein2015@yahoo.com

المستخلص

أجريت مقارنة بين الزيت الطيار للأجزاء النباتية الاورلق والسيقان لنبات العطرة Pelargonium graveolens كمضاد للأكسدة باستخدام المركب (DPPH)، كجذر حر ـهدفت هذه الدراسة إلى عزل وتثخيص المركبات الفعالة من الزيت الطيار. تم أستخلاص الزيت الطيار باستخدام طريقة التقطير المائي بواسطة جهاز (Clevenger) ،وقدرث مكونات الزيت الطيار

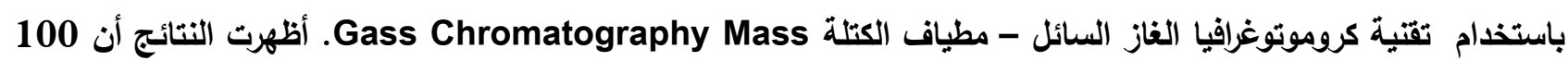

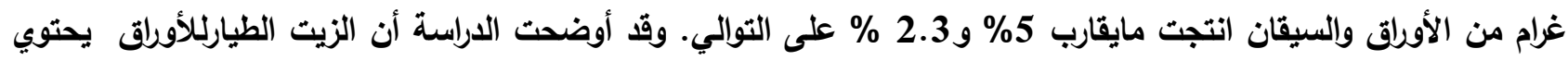

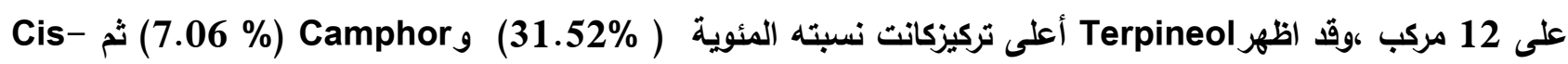
alpha-Bisabolene

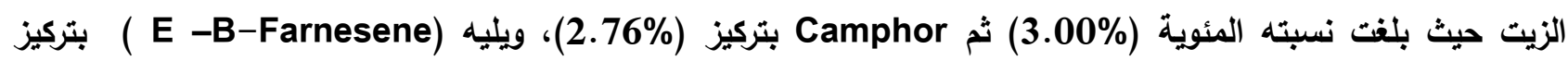
(2.31\%)، أظهرت النتائج الفعالية العالية للزيت الطيار لكل من الاورلق والسيقان عند تركيز 125 مايكروغرام مل بـ كمضاد

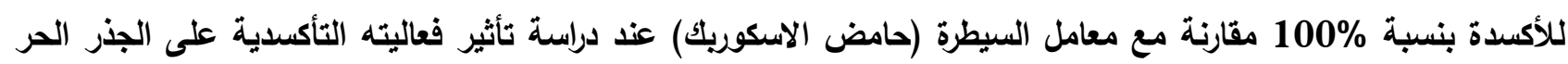
(DPPH) حيث لوحظ وجود فروق معنوية بين تراكيز الزيت الطيار لكل من الاورلق والسيقان.

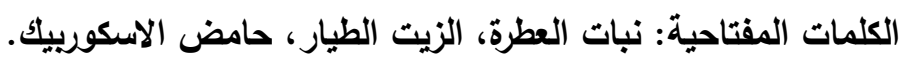




\section{INTRODUCTION}

The term Alternative Medicine has become very common these days and is based on the idea of using plants for medical therapeutic purposes . Medicinal plants are used as crud or raw material to extract the active ingredients involved in the manufacture of various medicinal drugs, blood thinners, laxatives , antibiotic , anti malaria and others (20).Herbal treatment derived from medicinal plants have been categorized by the World Health Organization (WHO) to be the most widely used around the world , and encouraged the use of herbal drugs which being safe and easy to store and more effective and side effects are almost none compared to chemical treatments (23).The existence of dictionaries of medicines (Pharmacopia), which is an important source of knowledge of medicinal plant species and their active ingredients ,alkaloids ,phenols and terpenoids are the main groups for the classification of secondary compounds responsible for the therapeutic properties of the plants that present in them (7) Aromatic oils were used in the manufacture of perfumes and as flavors for food, drink or healing for many diseases for thousands of years (12). Essential oils in Mesopotamia ,ancient Egypt ,China ,India and Persia have been known in many treatments and in various forms (5).At present time ,peppermint oil, Lavender oil, Geranium oil, Eucalyptus oil, Rose oil and Chamomile oil are the most widely traded (15).Geranium oil is an important oil because it is used in the pharmaceutical industry and herbal treatment. It possesses therapeutic properties as it can be used as sedatives, antidepressants, infections, diarrheal diseases, diabetes, stomach ulcers, kidney stones, urinary incontinence, preventing fluid retention in the body, in addition to its use in the cosmetics industry $(8,18,22)$. The plant has an aromatic smell that is similar to the scent of roses, this aromatic smell of the plant is due to its richness in aromatic essential oil. It is made up of several compounds, the most important of which are the main compounds responsible for aromatic smell which are linalool, geraniol, pinene, myrcene, citronellol, limonene and menthone (24).The essential oil of the plant is a nature source of antioxidant compounds, including, linalool, farnesene, pinene, camphor, myrcene, terpineol and camphene, the scientists pointed that these compounds have a clear effect as antioxidant $(2,9,16,19,22)$.

\section{MATERIALS AND METHODS}

The fresh parts of Pelargonium graveolens(Geranium) were collected during the growing period from nurseries of Zayuna in Baghdad .The plant was classified in the Iraqi National Herb /Ministry of Agriculture .The plant cleaned well from the dust and separated leaves, steams and kept in the refrigerator at $4^{0} \mathrm{c}$ for the purpose of oil extracting. $100 \mathrm{~g}$ of fresh leaves and steams of the plant were used for extraction volatile oils by hydro distillation using a Clevenger type apparatus .The oils was collected in dark sealed vial and kept in refrigerator at $4^{0} \mathrm{c}$ until use (26). The extracted volatile oils volumes and percentage were calculated according to the following equation :

Extracted oil ratio $\frac{\text { oil volume }}{\text { sample fresh weight }} \times 100$

The volatile oil of the plant parts (leaves ,steams) were analyzed by GC-Mass spectra at the conditions according to Table 1 and compared with the library of National Instituts of Standards and Technology (NIST) (14). The hydrogen electron donating ability of the corresponding volatile oils was measured from the bleaching of the purple colored methanol solution of 2,2-diphenyl picrylhydrazyl (DPPH) (1) . This assay uses the free radical DPPH, as a reagent, which prepared by adding $1.97 \mathrm{mg}$ of DPPH to 50 $\mathrm{ml}$ of absolute methanol to prepare solution with $0.1 \mathrm{mmol}$ concentration .Five concentrations were uses $(25,50,75,100,125$ $\mu \mathrm{g} \mathrm{ml}^{-1}$ ) of the essential oil (leaves ,steams), $3 \mathrm{ml}$ of oil was added to $1 \mathrm{ml}$ of methanolic solution of DPPH. The samples leaved in incubation at $37^{0} \mathrm{c}(310 \mathrm{~K})$ for 30 minutes, then measured by spectrophotometer ,the absorbance was read against blank at $517 \mathrm{~nm}$ .Ascorbic acid was used as standard control .The antioxidant capacity to scavenge the DPPH radical for the oils was calculated by the following equation :

Scavenging activity $\%=\frac{A 517 \mathrm{~nm} \text { control-A517nm sample }}{A 517 \mathrm{~nm} \text { control }} \times 100$ Where A $517 \mathrm{~nm}$ control is the absorbance of control reaction (containing methanol only), and A517 nm sample is the absorbance of samples. 
Table. 1. The conditions of GC-Mass

\begin{tabular}{|c|c|}
\hline Temperature program & \begin{tabular}{ccc}
\multicolumn{2}{l}{ Rate temperature $\left({ }^{0} \mathrm{c}\right)$} & Hold time (min) \\
& $50{ }^{0} \mathrm{c}$ & 3 \\
$10^{0} \mathrm{c}$ & $300^{0} \mathrm{c}$ & 10
\end{tabular} \\
\hline $\begin{array}{l}\text { Stationary phase } \\
\text { Mobile phase } \\
\text { Detector } \\
\text { Flow rate } \\
\text { Sample size }\end{array}$ & $\begin{array}{l}\text { Medium non polar } \\
\text { Carrier gas (Helium split ratio } 1.53 \mathrm{ml} \mathrm{min}^{-1} \text { ) } \\
\text { Detector mass } \\
8 \text { meter /min. } \\
1 \mu \mathrm{L}\end{array}$ \\
\hline
\end{tabular}

The results were analyzed statically using the statical program Statical Analysis System (25), to study the effect between the concentration and absorption of the volatile oil for leaves and steams ,and the effect between the concentration and percentage of antioxidant activity, compare the significant differences between means by choosing Least Significant Difference [LSD] in probability $\leq 0.05 \%$ (25).

\section{RESULTS AND DISCUSSION}

The water distillation of P.graveolens leaves and steams yield $5 \%$ and $2.3 \% \quad(\mathrm{v} / \mathrm{w})$ respectively. The GC-Mass analysis of leaves and steams essential oils are presented in Table 2 and Table 3, respectively. The results showed that volatile oil of leaves contains 12 compounds and the highest was Terpineol reaching $31.52 \%$ followed by Camphor 7.06 $\%$, followed by Cis-alpha-Bisabolene $4.38 \%$ and the volatile oil in steams contains 10 compounds and Linalool represented the highest $(3.00 \%)$, followed by Camphor (2.76 $\%)$, then(E) -B-Farnesene (2.31 \%), while Fayed (3) pointed out that the components of the volatile oil of P.graveolens which grown in Egypt contained: citonellol $29.90 \%$ \%transgeranoil $18.03 \%$ and 10-epi- $\gamma$-eudesmol 8.2\%

. Boukhris et al.,(17) indicated that the main composition of the volatile oil of P.graveolens grown in Tunisia were beta-citronellol $21.9 \%$, citronellylformate $13.2 \%$ and geraniol $11.1 \%$. The reason for the difference in the main components of the extracted volatile oil is due to the difference in the cultured area of plant where the change in the geographical nature and environmental conditions of the region has a significant impact on the quality and quantity of extracted volatile oil from the same species of the plant and cultured in different areas (8),the methods used to extract the volatile oil have an effect on the quality and quantity of the produced volatile oil (11).As well as the plant part used in extraction and the location of the leaves on the steams also have impact on the quality and quantity of the volatile oil (14). The DPPH free radical scavenging activities of leaves and steams volatile oils at various concentrations were determined and compared with that of the ascorbic acid as a standard antioxidant (Table 4). The results showed high volatile oil antioxidant activity in both leaves and steams at the concentration $125 \mathrm{\mu g} \mathrm{ml}^{-1}$ reached $100 \%$ compared with antioxidant activity percentage of Ascorbic Acid at $125 \mu \mathrm{g}$ $\mathrm{ml}^{-1}$ was $98.35 \%$.The percentage of antioxidant activity of the steams oil were $98.28 \%, 88.66 \%, 67.61 \%$ and $50.12 \%$ at $100,75,50,25 \mu \mathrm{g} \mathrm{ml}^{-1}$, respectively while the percentage of antioxidant activity of the leaves oil were $100 \%, 93.55 \%, 82.82 \%$ and $70.61 \%$ at $100,75,50,25 \mu \mathrm{g} \mathrm{m}{ }^{-1}$,respectively. The percentage of antioxidant activity of the ascorbic acid were 93.25\%,85.62\%,63.98\% and $51.30 \%$ at $100,75,50,25 \mu \mathrm{g} \mathrm{ml}^{-1}$, respectively. The results indicate significant differences between the volatile oil concentrations in both leaves and steams at $\leq 0.05$ probability. The results also indicate significant differences between the volatile oil of the leaves and the volatile oil of the steams at probability $\leq 0.05$. The results also indicate significant differences between the volatile oils and the ascorbic acid as a standard antioxidant at $\leq 0.05$ probability. The results of the current study proved the high efficiency of leaves and steams oils of P.graveolens as antioxidant reached to $100 \%$ which agreed with other researcher (10). The current study proved that the activity of the volatile oil of P.graveolens steams and leaves as antioxidant increased with increased concentration and also proved that the activity of the volatile oil of leaves as antioxidant for different concentration was the highest. The reason for this was the oil contain active compounds that characterized by high effectiveness as antioxidants and accounted for about $59.37 \%$ of the components of the volatile oil ,as evidenced by the analysis of GC-Mass as 
shown in (Table 2). The volatile oil of the steams as these components accounted for about $14.62 \%$ of the components of oil and this is comfirmed by the analysis of GC-Mass and as shown in (Table 3) and the most important of these compounds are linalool, farnesene ,pinene, camphor ,myrcene, terpineol ,camphene which have a clear effect as antioxidants $(2,9,16,19,21)$. In conclusion The P.graveolens plant contained a volatile oil in leaves and steams with the amount of the leaves oil higher than the oil of steams. The volatile oil of the leaves and steams contained similar compounds but differed in quantity and have a great economic importance such as Linalool ,Camphor, Pinene and Myrcene .The results showed that the volatile oil extracted from the leaves was highly effective as an antioxidant higher than the volatile oil of the steams .

Table .2. Compounds of the volatile oil of $P$. graveolens Leaves by GC-Mass technique

\begin{tabular}{|c|c|c|c|}
\hline NO. & Name of compound & Retation time & Area \% \\
\hline 1 & Bicyclo[3,1,1]hept-2-ene,2,6,6-trimethyl & 5.929 & 2.47 \\
\hline 2 & Bicyclo[4.1.0]heptane ,7-(1-methylethylidene) & 6.193 & 2.48 \\
\hline 3 & beta-pinene & 6.667 & 3.50 \\
\hline 4 & beta-Myrcene & 6.816 & 1.69 \\
\hline 5 & 1,7-Octanediol ,3,7-dimethyl & 8.178 & 0.48 \\
\hline 6 & beta-Linalool & 8.659 & 3.94 \\
\hline 7 & Camphor & 9.491 & 7.06 \\
\hline 8 & Terpineol & 7.586 & 31.52 \\
\hline 9 & alpha-Santoline alcohol & 9.874 & 0.30 \\
\hline 10 & Myrcenol & 10.218 & 1.48 \\
\hline 11 & Cis-.alpha-Bisabolene & 13.769 & 4.38 \\
\hline 12 & beta-Ocimene & 14.237 & 0.85 \\
\hline
\end{tabular}

Table.3. Compounds of the volatile oil of $P$. graveolens steams by GC-Mass Technique

\begin{tabular}{|c|c|c|c|}
\hline NO. & Name of compound & Retation time & Area\% \\
\hline 1 & beta-Myrcene & 3.378 & 0.87 \\
2 & 6,6-Dimethyl-2-methylenebicyclo [3.1.1] & 5.916 & 0.60 \\
3 & heptanes & & \\
4 & Bicyclo[4.1.0]heptane,7-(1-methylethylidene) & 6.179 & 0.69 \\
5 & beta-Pinene & 6.653 & 0.87 \\
6 & beta-Linalool & 7.376 & 3.00 \\
7 & Camphor & 8.423 & 2.76 \\
8 & Santolina alcohol & 9.477 & 1.26 \\
9 & alpha-linalool & 9.580 & 0.54 \\
10 & (E)-B-farnesene & 13.611 & 2.31 \\
\hline
\end{tabular}

Table .4.Percentage of the volatile oil efficiency of P.graveolens Leaves and Steams as an antioxidant compared with ascorbic acid

\begin{tabular}{|c|c|c|c|c|}
\hline \multirow[b]{2}{*}{$\begin{array}{c}\text { Concentration } \\
\text { Microgram/ } \\
\text { milliliter }\end{array}$} & \multicolumn{3}{|c|}{ Antioxidant activity \% } & \multirow[b]{2}{*}{ LSD } \\
\hline & Oil of Leaves & Oil of Steams & $\begin{array}{r}\text { Ascorbic } \\
\text { acid (Ve+ } \\
\text { control) } \\
\end{array}$ & \\
\hline 25 & $70.61 \pm 2.94 \mathrm{c}$ & $50.12 \pm 0.20 \mathrm{~d}$ & $51.30 \pm 2.11 \mathrm{~d}$ & $* 4.426$ \\
\hline 50 & $82.82 \pm 2.52 c$ & $67.61 \pm 0.26 d$ & $63.98 \pm 1.69 d$ & $* 4.281$ \\
\hline 75 & $93.55 \pm 0.30 \mathrm{~b}$ & $88.66 \pm 0.29 c$ & $85.62 \pm 1.07 c$ & * 3.178 \\
\hline 100 & $100.00 \pm 0.00 a$ & $98.28 \pm 0.31 b$ & $93.25 \pm 0.85 b$ & * 4.517 \\
\hline 125 & $100.00 \pm 0.00 a$ & $100.00 \pm 0.00 \mathrm{a}$ & $98.35 \pm 0.64 a$ & 2.974NS \\
\hline LSD & $* 3.576$ & * 0.708 & *3.067 & --- \\
\hline
\end{tabular}

\section{REFERENCES}

1.Adams. P. R. 2007. Identification Of Essential Oil Components By Gas Chromatography/ Mass Spectro metry, $4^{\text {th }}$. Allured Publishing Corporation, Carol Stream, I N llinois, U.S.A
2.Boukhris ;M. M. Simmonds ; S. Sayadi and M. Bouaziz .2013. Chemical composition and biological activities of polar extracts and essential oil of rose -scented geranium 
,Pelargonium graveolens. Phytotherapy

Research ,27: 1206-1213

3.Chang ; L. W .Szelo ; and P. Lin .2005.Trans ,Trans -2,4-Decadienal, a product found in cooking oil fumes, Induces cell proliferation and cytokine production Due to Reactive oxygen species in Human Bronchial Epithelial cells . Toxico logical Sciences, $87: 337-343$

4.Dzamic, A.; M. Sokovic; M. Ristic; S. Grujic; K. Mileski and P. Marin .2014.chemical composition, anti fungal and antioxidant activity of Pelargonium graveolens essential oil.Journal of Applied Pharmaceutical Science, 4(03):001 -005

5.Fayed. A. 2009.Antioxidant and Anticancer Activities of Citrus reticulate (Petitgrain Mandarin) and Pelargonium graveolens (Geranium)Essential Oils Research Journal of Agriculture and Biolo gical science ,5(5):740 747

6.Higley C. and A.Higley. 2001.Reference Guide for Essential Oils.Abundant Health, London, U.K., Book, pp. 64-64

7.Kassahun;B. Z. Zigene ;Z. Teferi ;S. Mekonnen ; B.Yalemtesfa ;F. Gebretenssay; H. Gebremeskel and B.Melka.2012.Yeild and yield components of rose -scented Geranium(Pelargonium graveolens ) as influenced by plant population density in Ethiopia . Int .J.Med .Arom .Plants , 2 : 60 -68

8.Kiran. G. and. V. Kaul. 2005 .Variation in essential oil composition of rose - scented geranium (Pelargonium sp.) distilled by different distillation techniques.Flavour and Fragnance J.,20:222-231

9.Lavabre M..2014.Chemical composition, antifungal and antioxidant activity of Pelargonium graveolens essential oil. Journal of Applied Pharmaceutical science 4(03),pp.001-005 .Belgrade, Esotheria

10.Lawless. J. 2001. The Illustrated Eucyclopedia of Essential Oils. Elements Books, Boston, U.S.A. 1:57-67

11.Machavariani ; N. G. T.D. Ivankova ; O. N.Sineva and L.Terekhora .2014. Isolation of eudophytic actinomycetes from medicinal plants of the moscow Region, Russia. World Appl. Sci. J., 30(11): 1599 - 1604

12.Misra A. and N.K.Srivastava .2010.Value addition of essential monoterpene oil in Geranium (Pelargonium graveolens ) on leaf positions for commercial exploitation . African
Journal of Agricultural Reasearch,5(15) :20772079

13.Pandey; A. M. Mohan; P.Pooja Singh and N. Tripathi .2015. Chemical Composition, Antioxidant and Antimicrobial Activitiesof the Essential Oil of Nepetahindostana(Roth) Haines from India.Rec .Nat.Prod .,9(2) :224233

14.Peeyush; K. M. Sapna,; M. Anushree, and S. Santosh, .2011. Insecticidal properties of Mentha species. Industrial Crops and Products, Vol.34, pp. 802-817

15.Petrovska. B. 2012. Historical review of medicinal plants usage. Pharmacognosy Reviews , 6 (11): 1-5

16.Ram.; M . D. Ram and S.K. Roy. 2003. Influence of an organic fertilizer nitrogen use efficiency and herb and essential oil yields in geranium (Pelargonium graveolens). Bioresource Technol 87:273-27

17.Rezaie ; M. R. Farhoosh, ; A. Sharif ; J. Asili and M.Iranshahi.2015.Chemical composition, antioxidant and antibacterial properties of bene (Pistaciaatlaticasub.sp. ) hull essential oil .Journal of Food Science and Technology,52(10):1-12

18.SAS. 2012. Statistical Analysis system, user's guide .Statistical . version 9.1th ed SAS .Inst. Inc. Cary. N.C.USA

19.Sharopov; F. M.Ahmed; P.Satyal ; W. Setzer and M.Wink .2017. Antioxidant activity and cytoto xicity of methanol extracts of geranium macrorrhizum and chemical composition of its essential oil. Journal of Medicinally Active Plants, 2(5) : 1-4

20.Simon;J. A. F. Chadwick and L.E.Crake .1984. Herbs, an Indexed Biography , Literature on Selected Herbs, and Aromatic and medicinal plants of the temperate zone, Connecticut, Archon Books, pp 1971 - 1980

21.Singam ; W. L.Charoenchai ; Ch. Monton and J.Suksaeree. 2015. Hydro distillation and volatile compounds identified from dried powder Jasmine (Jasminum sambac) by GCmass. Inter. J. pharm. Chem. Bio.Sci.,5(1): 315 -320 .

22.Tajkarimi ;M. S. Ibrahim and D.Cliver.2010.Antimicrobial herb and spice compounds in food .Food Control 21 :11991218

23.Tamilselvi.;M. S. Sundarammal and R.Thirugnan.2015.Antioxidant and cytotoxic 
activities of essential oil of ocimum canum sims from India . Journal of Saudi chemical society, $19: 97-100$

24.Wang; D. S. Sun ; L. Na Shi.; D. Ang Li; D. Wei ; Y.Zhang and J.Chen .2015.Chemical composition , antibacterial and antioxidant activities of the essential oils of Metaplexis japonica and their antibacterial components .International Journal of Food Science + Technology, $2: 50$

25.Wanger H. and S.Bladt.2009. Plant Drug Analysis.Springer Verlag Berlin - Heidelberg. pp :149- 151

26.Wei A. and T.Shibamoto (2007). Antioxidant activities and volatile constituents of various essential oils. J . Agaric. food Chem., 7 (5): 1737: 42 